\title{
Application of distributed registry \\ technologies (blockchain) and most \\ contractors in letter of credit settlements.
}

\author{
By \\ Dr. Igor B. Ilovaysky
}

PhD in Law, Candidate of Sciences (Jurisprudence), Associate Professor -

Volgograd Institute of management - branch

of the Russian presidential Academy of national economy and

public administration; Volgograd, Russia

Correspondence: dominno@rambler.ru 


\begin{abstract}
Distributed registry technology or blockchain allows to store and process information from all kinds of social sectors and internet websites to use a variety of electronic services in broad social spheres. Recently in the Russian Federation blockchains are being used in banking activities, including settlements under the letter of credit. Using blockchain in this case, strengthening the monitoring movement of funds and goods, provides secure relationship between the letter of credit payer and credit recipient. The purpose of this study is to consider the prospects of normative improvement of Russian law in the area of regulation both the most letter of credit form of settlements, and the use of distributed registry technology in its implementation. The article contains comparative analysis of the subject composition of the transgenic letter of credit, the experience of domestic banks in the implementation of the letter of credit on the blockchain platform and the use of smart contracts. The result of the study was the conclusion that the world community and the Russian legislator are at the initial stage therefore, it is necessary to establish unified international agreements in this field.
\end{abstract}

Keywords: letter of credit, blockchain, blockchain address, information technologies, opening of the letter of credit, smart contract. 


\section{Introduction}

In calculations between entrepreneurs, the letter of credit is alternative to prepayment, as provides relative risk parity of both the payer and the recipient of funds, and thus minimizes the risk of counter-default (Tynel A., Funk Y., Khvaley V. 1999; Demonovich Yu., Okuneva A., 2019). Moreover, along with payment tasks, it performs the function of short-term lending. This form of calculation is not a substitute in situations where it is necessary to sell products, and the integrity of the partner is questionable. The letter of credit has long been popular with the competent merchants, although with great complications. The development of information technology has made it possible to use blockchain platform and implemented on it smart contract. (Nagrodskaya V.B., 2019.; Zagidullin D.R., 2018). In order to assess the nature of the existing relations and to give them a legal assessment, including for the purposes of legal regulation it is necessary consistently consider the essence of the accreditation obligation, the legal nature of the blockchain and the prospects for using smart contracts.

\section{Materials and methods}

The analysis of the use of the letter of credit form for the implementation of smart contracts and blockchain technology is 
solved on the basis of a set of sources. These are the regulatory documents of the Government of the Russian Federation, namely the program «Digital Economy of the Russian Federation», approved by the Decree of the Government of the Russian Federation of 28.07.2017 No. 1632-r, and the regulations of the Central Bank of the Russian Federation such as the Regulations on the Rules for the implementation of Money Transfer, Approved by the Bank of Russia 19.06.2012 No. 383-P and ICC publications Uniform Customs and Practice for Documentary Credits (UCP 600). The scientific basis of the article is formed on the basis of scientific works of foreign (Schmitthoff C.M., Greenspan G., Tynel A., Funk Y., Khvaley V.) and Russian (Goncharov A.I., Inshakova A.O., Kazachenok S.Yu, Minbaleev A.V., Saveliev A.I.) scientists. Scientific research of the content of this article is based on the application of general scientific methods of knowledge such as dialectical, generalization, induction and deduction, analysis and synthesis, empirical description, classification. Also it was used private scientific methods such as legal-dogmatic, comparativelegal, structural-functional, and other. 


\section{Results}

The concept and participants of international settlements under the letter of credit

In Russian law, the regulation of the letter of credit relations is carried out on the basis of three most significant normative sources. This is chapter 46 of the Civil Code of the Russian Federation; Regulation on the rules for the transfer of funds (further - the Regulation) (The Regulations on the Rules for the implementation of Money Transfer, approved by the Bank of Russia 19.06.2012 No. 383-P) and publication of the International Chamber of Commerce No. 600 «Uniform Customs and Practice for Documentary Credits» (further referred to as the Uniform Rules) (Jan Ramberg, 2011). This obligation is most fully regulated in the last of these regulations. Although, it is just an international custom and is applied on the territory of the Russian Federation in accordance with Art. 5 Civil Code of the Russian Federation. Nevertheless, the letter of credit is most fully implemented and regulated precisely during international settlements, and therefore, to give it the most capacious characterization which we will use the international composition of entities (Mansurov G. Z., 2018 ), in which, in our opinion, there may be up to functional features eight 
and sometimes ten participants. Thus, the following entities are involved in the accreditation legal relation.

The letter of credit applicant (the payer, or the client of the issuing bank, or the letter of credit) is the debtor under the obligation, in which the letter of credit is provided as a form of payment, it is also called the basic contract (contract). This participant receives under such agreements the goods or for him works, services are provided, which he is obliged to pay.

The person (creditor) authorized under the letter of credit is the recipient of funds or, according to Article 2 of The Unified Rules, the beneficiary. Such entity shall supply to the payer the goods or render it services (works), and the latter shall pay them upon presentation of the documents provided in the terms of the letter of credit. They, as a rule, confirm the fact of shipment of goods (performance of works or services), their conformity to a certain quantity and (or) quality, can also certify the fulfillment of other conditions significant for the part. These documents are provided by the beneficiary to the bank, which accepted the payer's order to open the letter of credit in its favor. Such a bank is called the issuing bank. He is obliged to check the above documents and, if they meet the conditions set out in the letter of credit, to pay the recipient of the funds. 
One of the elements of the letter of credit obligation is to notify the recipient of funds about the opening in its favor of the letter of credit. In point 6.9. The provisions establish that such action is carried out by the acting bank or involves another third bank for this purpose. In international settlements, this action is carried out by a special entity - the advising bank. As an independent participant of settlements under the letter of credit, it is specified in Article 2 of The Unified Rules, according to which this subject is not responsible for payment to the recipient of funds but is obliged to carry out two legal actions. On the one hand, notify or according to bank terminology to inform the beneficiary of the opening of the letter of credit in his favor, and on the other, through the SWIFT system, verify on the external signs the authenticity of the letter of credit that he has approved.

In The Civil Code of the Russian Federation and in The Situation this subject is not established. In international calculations, the functions of the advising may be combined by other settlement participants: the issuing bank, performing or confirming the bank. As a result, in the legal literature, the acting and advising banks are often identified and understood as one person (Clive M.Schmittgoff, 1990). In practice, they can be different credit organizations. In any case, the payer and the 
beneficiary, signing the agreement under which payments are made, should specify which bank will be adviser bank.

The process of advising at the letter of credit is great legal importance. Firstly, the beneficiary, having received the terms of the letter of credit opened by the payer from the advising bank, can issue a letter of credit to the bank for compliance with the provisions of the main agreement (i.e. check, in essence, the payer for good faith). And, if it exists and meets the interests of the beneficiary, then it carries out the so-called reverse advising, i.e. agrees to execute the letter of credit on these conditions. If there is no coincidence, and the conditions of the letter of credit opened in the issuing bank contradict the rules established in the main contract, then the beneficiary has the right to either demand to open a letter of credit on previously agreed terms or refuse to fulfill the main obligation. Secondly, unless otherwise stated in this agreement between the parties, by carrying out the reverse order, the beneficiary also agrees to pay the services of the advising bank.

The beneficiary may insist on securing the obligation of the issuing bank by confirming the letter of credit from another bank. Confirmation, by virtue of Article 870 of the Civil Code of the Russian Federation and Article 8 of The Unified Rules, means acceptance of an additional obligation of the issuing bank to pay in 
accordance with the terms of the letter of credit. The attraction as such a subject of a new participant, other than the issuing bank or the performing bank, gives a firm guarantee from a third party, from which, in case of improper performance of the accreditation obligation on the part of the listed credit organizations, the recipient of the funds may demand payment (Frolova S.N., 2018).

According to Clause 3, Article 867 of the Civil Code of the Russian Federation, settlements under a letter of credit can occur through the use of covered and uncovered types of letter of credit. With a letter of credit covered, the payment amount is credited for the entire term of the letter of credit to the account of the performing bank. With an open letter of credit, this bank is allowed to write off the amount of the letter of credit from its correspondent account of the issuing bank, that is with this type of letter of credit, correspondent relations between these banks are required. Thus, the executing bank receives a kind of security for payments under the letter of credit from the issuing bank. In international settlements, covered letters of credit are used very rarely, just as not often direct correspondent relations are established between banks.

Under such conditions, the relationship between the issuing bank and the executing bank is carried out through the general correspondent bank in order to speed up the execution of the letter 
of credit, the issuing bank may request the executing bank to pay the beneficiary directly from its own funds, and in order to guarantee that the bank will return the paid amounts, the issuer, simultaneously with the opening of the letter of credit, issues a settlement authority to the correspondent, in accordance with which he assumes the obligations of a settlement to provide compensation to the executing bank for the issuing bank. The correspondent bank, if it accepts such duties, is called a reimbursing bank.

Since all payments under the letter of credit are made in noncash, the money sent to the beneficiary must be credited to the settlement account opened in his bank, i.e. the beneficiary bank. If you graphically represent all participants who may be involved in the performance of the accreditation obligations, then the relations between them will develop as shown in Figure 1.

The number of subjects with different rights and obligations in relation to each other in the settlement under the letter of credit is equal to eight participants: the payer of funds, the issuing bank, the reimbursing bank, the executing bank, the confirming bank, the advising bank, the receiving bank and the recipient of funds.

In international practice, and in the Russian Federation after the introduction of changes in the Civil Code of the Russian 
Federation of July 26, 2010. (See Article 77.0.1 of the Civil Code of the Russian Federation), it is possible to apply the so-called transfer or transfer letter of credit. Under the terms of such settlements, the beneficiary may specify one or more persons for whom payment under the letter of credit can be made. As a rule, such entities include co-contractors (subcontractors) of the beneficiary under the main contract. In paragraph «b» of article 38 of the Unified Rules for such kind of entities, second beneficiaries are called, and in paragraph 2 of article 870.1 of the Civil Code of the Russian Federation - second beneficiaries.

Thus, the above scheme can be supplemented by these participants. Moreover, one person can act as a payer of funds under a letter of credit. Other person can act as a recipient of goods (services or works) from the beneficiary, it's mean another subject of the letter of credit appears, which can be called the «beneficiary».

The above makes it possible to say that the letter of credit is a complex obligation with many actors performing various functions, complementing and supporting each other. In general, a legal relationship is created that allows a high degree of guarantee from the buyer to receive the goods, and from the seller to pay for it. 
The technology of blockchain and its use of smart contracts in the payment of letters of credit

Blockchain technology is viewed as a certain information system, which is a register of information, as well as its processing technologies, including the accumulation, the storage of accurate data confirming the totality of property and other rights and responsibilities of their owners and allowing for various legally significant actions, including electronic calculations. From a legal point of view, blockchain represents some decentralized electronic distributed database, a kind of accounting Ledger in which all recorded actions committed against any asset (for example, cashless, electronic money, or undocumentary securities, etc.) are collected. And the work of such a base is based on cryptographic algorithms (Minbaleev A.V. Safronov E.G., 1918; Mogayar U., 2018). Although this type of feature of blockchain does not in all correlate with the provisions of Art.1260 of the Civil Code of the Russian Federation on databases, nevertheless, such technology allows you to store and process information from various public areas, and on the basis of various sites collected in a single chain, to use various electronic services in broad social spheres. It can be entrepreneurship, education, banking, state and municipal management and other directions. 
The good example of this technology in the Russian Federation can be the portal of State Services, which combined the work of servers of several state bodies and institutions. Among foreign examples of blockchain, you can consider the EmcSSL service, which allows you to combine the user's work on an unlimited number of social networking sites under a single key which reflected in the client certificate received when connected to the specified service. At the same time, you do not need to log in to a particular resource and perform special authentication, since the system will independently provide secure work on the site. All sites will use the same key which you change anytime and it will work for all websites. (Greenspan G., 2016; Inshakova Agnessa O., Goncharov Alexandr I., Kazachenok Svetlana Y., 2019).

The fact that blockchain technology can safely handle a vast array of information that requires identity binding to individuals (participants), and that such information cannot be changed or removed without the consent of their owners, makes the technology very promising. In particular, the use of the technology under consideration is possible for the creation of automated, programmed contracts, such ac agreements that can be concluded and implemented in whole or in part without human participation. Such agreements received the generalized name «Smart-contrakts» 
(Saveliev A.I., 2016). In our opinion, it is necessary to call this kind of phenomenon a treaty (contract) with a sufficient degree of convention. In this case, one can agree with the opinion of I.A. Mitrofanova, who claims that $« . .$. the smart contract should be considered not as a separate specific type of obligation, but as a special way of fulfilling obligations under the contract» (Mitrofanova I.A., 2018). And as you know of amendments to the Civil Code of the Russian Federation by Federal Law No. 34-FZ, adopted by the State Duma on March 12, 2019, the smart contract is generally a form of transaction - using electronic or other technical means (in the form of an electronic algorithm or, otherwise, a program for computers). In this case, such a form is equated with the written form of the transaction. Thus, the legislator said that a smart contract is not a way of execution, but a form of transaction (Agibalova E.N., 2019; Efimova L.G., 2019).

The use of «smart contracts» (legally significant actions) in the settlement of letters of credit is indicative. Thus, on December 20, 2016, between the Russian airline «S7 Airlines», which acted as a contractor, Alfa Bank, which performed the role of issuing bank and some executor, a transaction was concluded for the implementation of works with their payment through an irrevocable covered letter of credit and using smart contracts. Thus, only three 
subjects participated in the undertaking. The conditions for its execution, namely the type of works performed for S7, the amount of the deal, the date of its opening and closing, the names of the parties and their INN, were fixed in the block. In order to execute the transaction, it seems that the parties have previously entered into an agreement on the use of public block addresses as an electronic signature. A. Zaitsev, considering the said legal relations, correctly, notes that the actual legal functions in the operation of smart contracts were not much, and their use was reduced to providing exclusively technical tasks (Zaitsev A.M., 2018).

Another interesting domestic experience of using the letter of credit, which was carried out by Raiffeisenbank. On June 22, 2017, Marina Smanzer made a report at the Blockchain \& Bitcoin Conference in St. Petersburg, according to her participants in this commitment, three subjects also acted: Buyer, seller and bank (the issuing bank, ie Raiffeisen Bank). The buyer and the Seller have concluded a contract for the provision of certain goods. An important condition was that the fact that they were granted could be identified automatically. For example, the basic agreement involves the sale of real estate or securities, or shares in the authorized capital of a legal entity. The fact of transfer of ownership of such property can be checked on the basis of 
information in the submitted documents, and on the basis of information in external sources (for example, in a single state register of real estate).

Further operational support for the deal is provided through the blockchain platform. The parties divided it into several stages.

First, the Buyer created a smart contract - «Application for letter of credit» (Application), which received the status as «New». The address Of The Letter Of Credit was placed in the Bank's and Seller's mailboxes. The buyer attached to The Application a formalized electronic document describing the transaction details and necessary informal documents, after attaching all necessary documents, the Buyer transferred The Application to InBank status.

Secondly, the Bank automatically (for formalized electronic documents) or with the use of experts (for informal documents) checked this transaction. For example, he sent a request to the bank systems to check the client details in the client data catalog, to confirm the balance of the account and reserve funds, for purposes of currency control, and for other checks. If the Bank has any claims on the contents of the transaction or attached documents, it refuses to accept The Application and sets it the status of rejected. If the Bank agrees to accept The Application for execution, it is set to the status confirmed. 
Thirdly, on the basis of a formalized electronic document, the Bank's accounting systems carried out the necessary operations: Transfer of the letter of credit from the client's account to the «cover account», cancellation of the Commission, etc. The bank issued a smart contract «letter of credit» (hereinafter «letter of credit»), which received the status of New. The address of The Letter Of Credit was placed in the Bank's and Seller's mailboxes. The Letter of Credit kept the address of The Application, which allowed to automatically track their key statuses so that the Buyer can monitor the status of the transaction. The Bank attached to The Letter of Credit a formalized electronic document (formed automatically from the terms of The Application) with a description of the transaction details, other necessary documents and established the status as «Released» to it. The application was also transferred to this status. When you move to it, the Accreditation automatically queued two requests:

- letter Of Credit expiry control request. It is triggered when the current date exceeds the validity Of The Letter Of Credit and this obligation can no longer be fulfilled;

- request pending contract execution it is a specific template that defines the contents of the deal that is triggered if the conditions laid down in it are fulfilled. 
Fourth, the Seller, after studying the issued Letter of Credit, could refuse to accept it. In this case, he transferred it to the status Invalid. The letter of credit must be canceled and further work with it becomes impossible the status of The Application also switches to Invalid. If the letter of Credit expires event is the first to occur, it is set to override status and the claim status and further operations are not possible. In this case, automatic orders are sent to the Bank's accounting systems to initiate transactions corresponding to the cancellation of the letter of credit.

Fifth, if the contract execution event is the first to occur, including when the Seller attaches electronic documents, the Credit has switched to InBank status. When you move to this status, it was automatically queued to wait for payment execution requests and removed from the queue the expiration control request. The Bank, on the basis of a formalized electronic document attached to The Letter Of Credit, performed payment in favor of the Seller by transferring the order to its settlement system and performing Payment outside the block currency.

Sixthly, after the event of execution of the payment, the Credit was switched to the Closed status. The status Of The Application also switches to Closed, and the obligation was generally considered fulfilled and completed (Schmanzer M., 2019). 


\section{Conclusion}

When comparing the content and subjective composition of the classic (in our case foreign economic) accreditation legal relationship, which was given in the first part of this study, and the obligations under the letter of credit using smart contracts, it is necessary to recognize that the last transactions are carried out on a much more modest scale (by the number of such operations carried out, by the subjective composition, obligations and their linkages, etc.).

If the first form of the letter of credit is used for a long time and takes the third most popular place among the forms of non-cash settlements (Kazachenok O.P., 2018), then the letter of credit on the platform blockchain only begins to be mastered by interested persons (Shapiro I.E., 2018.).

Moreover, in the classical form of the letter of credit, up to eight or more entities can participate, and the letter of credit on the basis of blockchain is sold only between three entities and within the scope of such a platform of one bank. This credit organization simultaneously performs the functions of both the issuing bank and the executing and lending bank, and the beneficiary and payer bank, i.e. the buyer (payer) and the seller (beneficiary) should be the clients of this bank, the wish for the execution of the basic agreement. 
A small number of participants also dictate the poor (trivial) content of the accreditation legal relationship using smart contracts. In fact, smart-contracts perform auxiliary technical tasks in the implementation of three legally significant actions - opening, closing and advises (notice of the opening of the letter of credit). Such a nature of obligations gives grounds for some doubts: «If so, what was stated in the second part of this work is similar to the obligations of Chapter 47.1 of the Civil Code of the Russian Federation on escrow» (Wilhelm M., 2011; Konyachin N.Ya., 2019.).

It is unlikely that such a form of credit will be possible, at least at the present time in foreign economic activity in a situation where the counterparties will be located in significantly remote countries, and their service will be carried out in different credit organizations (Dmitrieva G.K., 2019.). And yet, if SWIFT's information resources are consolidated with similar platforms by other major banks, creating a global banking network like superblockchain is both feasible and realistic. However, this creates the need for legal regulation of such banking operations and transactions, and it should, in our view, be the national legislation of individual countries, harmonized with the unified international agreements, and not corporate acts in the field of settlements, which can be observed at the level of SWIFT, and not customs created, For example, the International Chamber of Commerce for the 
Regulation of Transborder Credit Settlements (see Uniform Customs and Practice for Documentary Credits (UCP 600) and other ICC regulations adopted in their development).

Figure 1. «Subjects of settlements under the letter of credit»

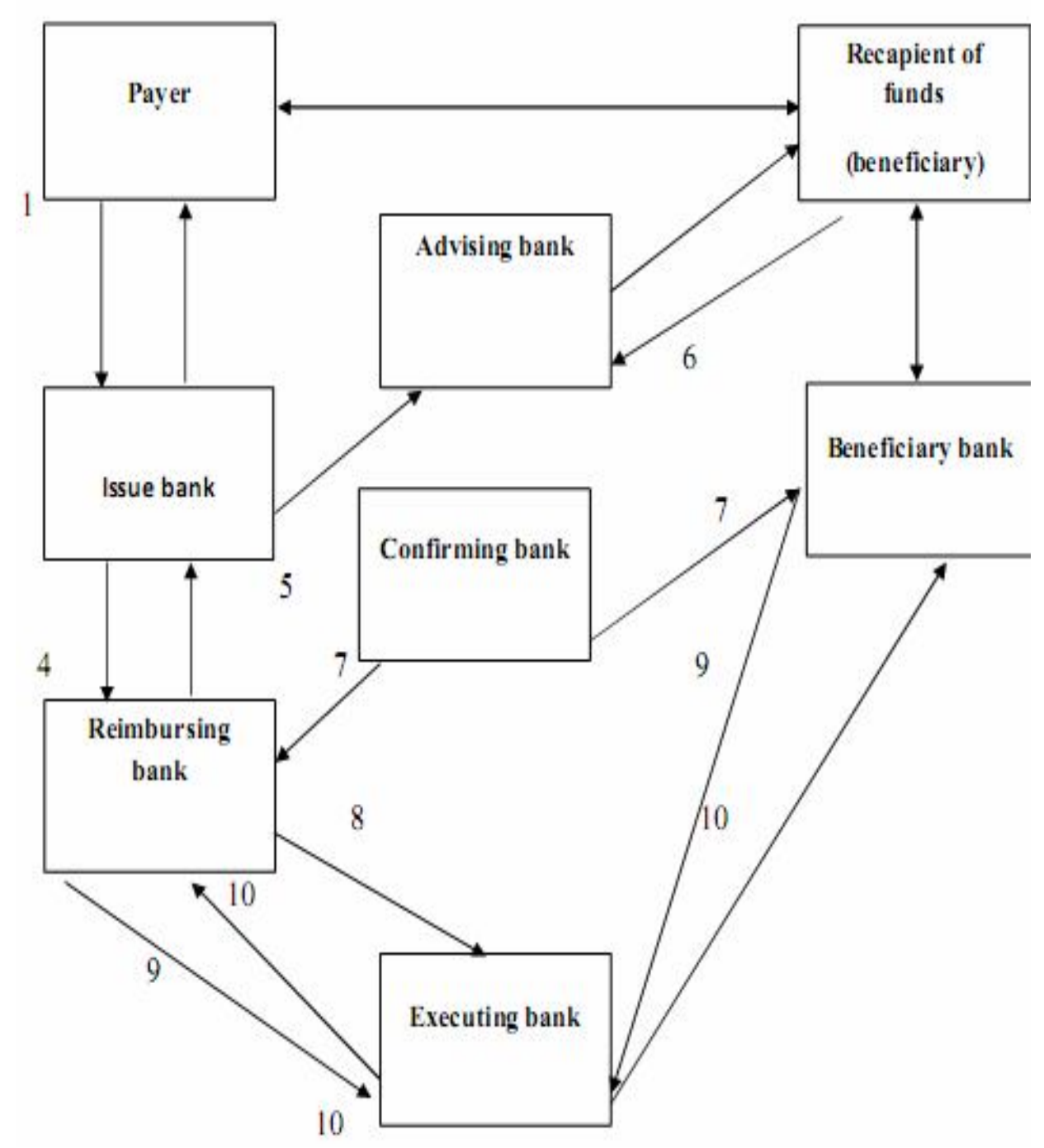


Igor B. Ilovaysky . عدد خاص بالمؤتمر الدولى السنوى العشرون

1. The main obligation in which the letter of credit is provided as a form of payment.

2. Order to open letter of credit.

3. Issuance of reimbursement authority.

4. Commitment of reimbursement obligations.

5. Order to notify (advise) the beneficiary of the opening of the letter of credit.

6. Notification of the beneficiary of the opening of the letter of credit.

7. Reverse advising.

8. Instruction to secure the obligations of the issuing bank to the beneficiary through confirmation of the letter of credit.

9. Letter of credit confirmation.

10. Crediting funds to the beneficiary's current account.

11. Submission of documents attesting to the fulfillment of the basic obligation. 


\section{References}

1. Agibalova E.N., 2019. The subject of civil-law regulation of smart contracts // Journal of Legal Studies. Part 4. No. 2. p. 5357.

2. Demonovich Yu., Okuneva A., 2019. Letters of credit: New opportunities and possible difficulties // International banking operations. No. 2. p.36.

3. Dmitrieva G.K., 2019. Digital financial assets: Conflict of laws issues // Actual problems of Russian law. No. 5. p. 120 - 128.

4. Efimova L.G., 2019. Once again about the concept and legal nature of electronic form of transaction // lex rustica. No. 8. p. 29-137.

5. Frolova S.N., 2018. Letters of credit as a method of non-cash settlements: Application of modern technologies in the use of settlements by letters of credit // actual problems of modern society and ways of their solution in conditions of transition to digital economy Materials of XIV International scientific conference: In 4 parts. p. 475-483.

6. Greenspan G., 2016. Why Many Smart Contract Use Cases Are Simply Impossible. https://www.coindesk.com/three-smartcontract-misconceptions (дата обращения: 24.08.2019). 
7. Inshakova Agnessa O., Goncharov Alexandr I., Kazachenok Svetlana Y., 2019. Legal Regulation of the Syndicated Lending: Banking Innovations in Contemporary Russia. Advances in Intelligent Systems and Computing, Pyatigorsk, Russia:, pp 368377.

8. Jan Ramberg, 2011. International Commercial Transactions. ICC Publication No. 711E. Infotropic Media, Moscow, Russia .p.896.

9. Kazachenok O.P., 2018. The legal regime of bank responsibility in the settlement of letters of credit // Entrepreneurial law. The application «Law and Business». No. 1. pp. 22-25.

10. Konyachin N.Ya., 2019. The difference of the account of an escru from the letter of credit // Accounting. No. 1. p. 134-138.

11. Mansurov G. Z., 2018. Innovation of accreditation law as a result of reception of acts of the International Chamber of Commerce // Law of Russia: Experience, analysis, practice. No. 6. p. 50 - 54.

12. Minbaleev A.V. Safronov E.G., 2018. The legal nature of blockchain // Bulletin of SUSU. Series «Law». No. 2, p.96.

13. Mitrofanova I.A., 2018. Legislative regulation of smart contracts: problems and development prospects // Legal Concept $=$ Legal paradigm. No. 4, pp.25-26. 
14. Mogayar U., 2018. Blockchains for business. Eksmo, Moscow, Russia, p. 73-74.

15. Nagrodskaya V.B., 2019. New technologies (blockchain / artificial intelligence) in the service of law: A scientific and methodical manual. Prospect, Moscow, Russia, p. 28-29.

16. Obruchnikov A.V., Solomatin D.I., 2018. Digital letter of credit using blockchain technology. Publishing of Voronezh State University. Voronezh, Russia, pp. 215-221.

17. Regulation on the rules for the transfer of funds (approved by the Bank of Russia 06.19.2012 No. 383-P) (as amended on 10/11/2018), 2012 // Bank of Russia Bulletin. No. 34, pp.51-59.

18. Savelyev A.I., 2016. Contract law 2.0: «smart» contracts as the beginning of the end of the classic contract law // Bulletin of civil law. No. 3, pp.32-60.

19. Schmitthoff C.M., 1990. Export trade: The law and practice of international trade. Steven \& Sons, London, p.202.

20. Shapiro I.E., 2018. Will blockchain be able to revive the letter of credit market? // Financial research. No. 3 (60). p. 81-84

21. Smantser M. Blockchain platform for trade finance transactions based on smart contracts URL: https://habr.com/ru/company/raiffeisenbank/blog/332756/ (accessed 24 August 2019). 
Igor B. Ilovaysky .

عدد خاص بالمؤتمر الدولى السنوى العشرون

22. Tynel A., Funk I., Khvaley V., 1999. The course of international commercial law. Amalfey Publishing House, Minsk, p.339.

23. Wilhelm M., 2011. Treuhandmodelle - mehr als nur Insolvenzsicherung. Anwendungsbereiche der Treuhand. Frankfurt, p.76.

24. Zagidullin D.R., 2018. Possibility of using blockchain technology for the realization of digital letters of credit in the Russian economy // Science almanac. No. 7-1 (45). p. 33-35.

25. Zaitsev A.M., 2018. Smart contracts: concept and prospects of use // Arbitration practice for lawyers. No. 4 (32). p. 28-34. 